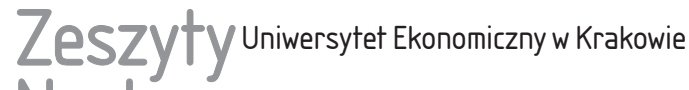 Naukowe
}

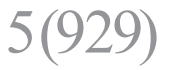

ISSN 1898-6447

Zesz. Nauk. UEK, 2014; 5 (929): 57-74 DOI: 10.15678/ZNUEK.2014.0929.0504

Krzysztof Firlej

Katedra Strategii Zarządzania i Rozwoju Organizacji

Uniwersytet Ekonomiczny w Krakowie

\section{Aleksandra Bargiet}

Studia Doktoranckie Wydziału Zarządzania

Uniwersytet Ekonomiczny w Krakowie

\section{Nowoczesne paradygmaty zarządzania jako element podnoszenia wartości spółek przemysłu spożywczego}

\section{Streszczenie}

W artykule poddano teoretycznym i analitycznym rozważaniom nowoczesne paradygmaty zarządzania, zakładając, że są one elementem kierunkującym funkcjonowanie spółek przemysłu spożywczego. W części teoretycznej zaprezentowano ewolucję i stan obecny paradygmatów zarządzania, które zbadano w kontekście wykorzystania ich w procesie zarządzania spółkami przemysłu spożywczego. Sprawdzono, jak poszczególne paradygmaty zarządzania realizowane są w funkcjonowaniu spółek, zauważając, że właściwe ich wykorzystanie wpływa wymiernie na podnoszenie wartości firmy i zajmowanie przez nią coraz lepszej pozycji rynkowej. Analiza działań z tym związanych potwierdziła, że badane spółki są bardzo zainteresowane realizacją wszelkiego rodzaju działań podnoszących ich wartość rynkową, śledzą na bieżąco badania naukowe, zachowania konkurencji i starają się z ich wykorzystaniem osiągać zamierzone cele.

Słowa kluczowe: zarządzanie przedsiębiorstwami, współczesne paradygmaty zarządzania, spółki przemysłu spożywczego, wartość i pozycja rynkowa przedsiębiorstw. 


\section{Wstęp}

Funkcjonowanie przedsiębiorstw spożywczych w Polsce prawie dziesięć lat po akcesji do Unii Europejskiej wymaga stosowania nowoczesnych form i instrumentów zarządzania, pomocnych w spełnianiu wysokich i wciąż rosnących wymagań konsumenckich, które są wyznacznikiem zachowań wielkich sieci sprzedaży detalicznej, pragnących zaspokoić je w jak największym stopniu. Głównym celem przedsiębiorstwa jest osiągnięcie i utrzymanie konkurencyjnych cen, minimalizacja kosztów i zachowanie optymalnych proporcji pomiędzy poziomem utrzymania jakości a utrzymaniem jej zgodności z obowiązującymi normami. Nie mniej ważne jest osiągnięcie przez przedsiębiorstwo wysokiej rentowności, co przy ponoszeniu coraz wyższych kosztów tworzenia należytego wizerunku i pozytywnej opinii o marce jest przedsięwzięciem niezwykle trudnym w realizacji. Przeszkody stanowić mogą także: rozdrobnienie rynku, duża konkurencja asortymentowa, szeroki rozwój nowoczesnych i funkcjonalnych opakowań, skracający się cykl życia produktów i rosnące koszty promocji. Każde przedsiębiorstwo to zbiór wyjątkowych zasobów, które są różnego rodzaju aktywami umożliwiającymi firmom realizowanie strategii prowadzącej do wzrostu ich efektywności, skuteczności oraz konkurencyjności [Firlej 2008b]. W realizacji wytyczonych strategii działania konieczne jest określenie ogółu działań umożliwiających efektywne wykorzystanie zarówno kapitału ludzkiego, jak i zgromadzonego kapitału, umożliwiających osiągnięcie celu według sformułowanych założeń. Założenia te stanowią rodzaj instrumentów i uwarunkowań koniecznych do spełnienia i uwzględnienia w procesach planowania, organizowania, koordynowania i kontrolowania każdego przedsiębiorstwa funkcjonującego w gospodarce rynkowej.

\section{Obszar badań, cel i hipoteza badawcza}

W celu przeprowadzenia badania nowoczesnych paradygmatów zarządzania, które są wykorzystywane w bieżącej działalności przedsiębiorstw spożywczych, posłużono się informacjami dotyczącymi spółek należących do sektora spożywczego Warszawskiej Giełdy Papierów Wartościowych, które tworzą indeks WIG-Spożywczy. Sektor spożywczy w przeszłości odgrywał o wiele większą rolę niż dzisiaj, aczkolwiek ciągły wzrost cen produktów żywnościowych może spowodować szersze nim zainteresowanie. Spółki z branży spożywczej są zgrupowane na podstawie kryterium sektorowego w indeksie WIG-Spożywczy, w którego skład wchodzi 25 spółek $^{1}$. Na światowych rynkach finansowych coraz częściej

${ }^{1}$ W skład indeksu WIG-Spożywczy 3.07.2013 r. wchodziły następujące spółki: Agroton Public Limited w Nikozji, AB Agrowill Group w Wilnie, Ambra SA w Warszawie, Astarta Holding NV 
zauważalne jest zainteresowanie produktami żywnościowymi, a ich indeksy stają się przedmiotem spekulacji od czasu ostatniego kryzysu² ${ }^{2}$. Podobnie spółki sektora spożywczego są atrakcyjne dla inwestorów, chociaż stanowiły w 2012 r. niespełna $3 \%$ wartości całej giełdy i $10 \%$ kapitalizacji firm z sektora przemysłowego. Głównym celem artykułu jest wskazanie, zbadanie i opisanie nowoczesnych paradygmatów zarządzania, które są wykorzystywane w bieżącej działalności przedsiębiorstw spożywczych. Autorzy opracowania stawiają tezę, że ciągłe pogłębianie działań służących dalszej adaptacji założeń wynikających ze współczesnych paradygmatów zarządzania przez menedżerów spółek spożywczych umożliwia podnoszenie wartości i pozycji rynkowej spółek przemysłu spożywczego.

\section{Paradygmaty zarządzania - ewolucja i stan obecny}

Paradygmaty w rozumieniu nauk społecznych przedstawiają obraz podstawowych założeń, na których oparta jest rzeczywistość, i określają podstawowy kontekst funkcjonowania danej dziedziny. Konsekwencją przyjęcia do świadomości wytycznych jest postawa polegająca na podejmowaniu działań zgodnych ze sformułowanymi założeniami.

W odmienny sposób pojmowane są paradygmaty w kontekście nauk społecznych i przyrodniczych, a istniejące różnice wynikają z filozoficznych założeń tych dziedzin. Nauki przyrodnicze, opierając się na zastanej rzeczywistości, postrzegają paradygmaty jako niezmienne cechy zjawisk, a przyjęte teorie nie wywierają wpływu na badany obszar i są jedynie przełożeniem rzeczywistości. Nauki społeczne poprzez swój zmienny i ahistoryczny charakter cechują się dużo bardziej dynamicznym podejściem do istniejących zjawisk, a przyjmowane paradygmaty ulegają ewolucji, zgodnie z rozwojem poszczególnych dyscyplin. Nauki o zarządzaniu, stanowiąc element nauk społecznych, odnoszą się w szczególny sposób do paradygmatów. Od początku lat 30 . XX w. podejmowano próby usystematyzowania rzeczywistości na kanwie dwóch rodzajów założeń. Pierwsza grupa odnosiła się do teorii nauki, przedstawiając zarządzanie w kontekście przedsię-

z siedzibą w Amsterdamie, Colian SA w Opatówku, Polski Koncern Mięsny Duda SA w Warszawie, Graal SA w Wejherowie, Industrial Milk Company SA w Luksemburgu, Indykpol SA w Olsztynie, Zakłady Mięsne Henryk Kania SA w Pszczynie, Kernel Holding SA w Luksemburgu, Kofola SA w Warszawie, Zakłady Tłuszczowe Kruszwica SA w Kruszwicy, KSG Agro SA w Luksemburgu, Makarony Polskie SA w Rzeszowie, Zakłady Przemysłu Cukierniczego Mieszko SA w Warszawie, Milkiland NV w Amsterdamie, Zakłady Przemysłu Cukierniczego Otmuchów SA w Otmuchowie, Ovostar Union N.V. w Amsterdamie, Pamapol SA w Ruścu, PBS Finanse SA w Sanoku, Przedsiębiorstwo Przemysłu Spożywczego PEPEES SA w Łomży, SEKO SA w Chojnicach, Belvedere SA w Beaune, we Francji i Wawel SA w Krakowie.

${ }^{2}$ Szerzej na ten temat: [Firlej 2008a]. 
biorstwa biznesowego, posiadającego jedyną właściwą strukturę organizacyjną i zarządzającą ludźmi w jedyny właściwy sposób [Drucker 2002, s. 11-13]. Druga grupa założeń odwoływała się do praktyki zarządzania, wymieniając jako podstawowe następujące elementy [Drucker 2002, s. 113]:

- technologie, rynki i użytkownicy końcowi są z góry określeni,

- zasięg zarządzania jest zdefiniowany poprzez ograniczenia prawne,

- zarządzanie jest skoncentrowane wewnętrznie,

- gospodarka rozumiana jako państwo, w którym funkcjonuje podmiot, jest swoistym środowiskiem przedsiębiorstwa i zarządu.

W ostatnich dwóch dekadach zauważano konieczność weryfikacji przyjętych wcześniej założeń, podejmując próby ich skorygowania o obecnie przyjęte praktyki zarządzania. P.F. Drucker wielokrotnie w publikacjach podaje w wątpliwość aktualność owych wywodów, stanowiących podstawy nauki o zarządzaniu (np. Management Challenges for the 21st Century - 1999 r., The Essential Drucker - 2001 r.). Dokonuje analizy każdego z nich i odnosząc się do aktualnej praktyki zarządzania organizacjami, podważa zasadność przyjmowania wspomnianych założeń za prawdziwe i ponadczasowe [Drucker 2000, s. 3-40]. Przedstawiona przez niego argumentacja pozwala odrzucić aktualność założenia o jedynej właściwej strukturze organizacyjnej, właściwym sposobie zarządzania ludźmi czy zarządzaniu prowadzonym jedynie w jednostkach biznesowych. Pozostałe założenia odnoszące się do praktyki zarządzania również tracą na znaczeniu, przyjmując odmienny kształt we współczesnych realiach. W konsekwencji przytoczonych wywodów przyjęto za aktualne następujące paradygmaty nauk o zarządzaniu [Drucker 2000, s. 15-40]:

1. Zarządzanie jest swoistą cechą każdej organizacji i nie ogranicza się do jednostek o charakterze biznesowym. Organizacje non profit, administracja publiczna czy instytucje kościelne tylko w nieznacznym stopniu stosują odmienny model zarządzania, związany ze specyfiką ich funkcjonowania.

2. Zarządzana organizacja powinna korzystać z różnych struktur organizacyjnych, dopasowanych do jej profilu działalności. Optymalne warunki działania powinna zapewnić koncentracja na jednej właściwej strukturze wypracowanej na drodze ciągłych poszukiwań i rozwoju.

3. Nie istnieje jeden właściwy sposób kierowania ludźmi. Obecnie zadaniem kadry zarządzającej jest przewodniczenie ludziom, czyli wykorzystanie umiejętności i wiedzy każdego członka zespołu w celu osiągnięcia optymalnych efektów pracy.

4. Podstawą budowania procesu zarządzania w organizacjach są potrzeby klientów oraz tworzenie dla nich wartości. Uważane niegdyś za kluczowe: technologia, produkt oraz rynki finalnych użytkowników w kreowanym współcześnie marketingowym podejściu do prowadzenia działalności nie stanowią punktu wyjścia dla zarządzania. 
5. Zarządzanie nie jest ograniczone sferą prawną i powinno mieć charakter funkcjonalny, tzn. obejmować cały proces. Jego zasięg określany jest operacyjnie. Zarządzanie obecnie skupia się na osiąganiu wyników i kreowaniu działań w trakcie tworzenia całego procesu ekonomicznego.

6. Polityczne granice państwa nie powinny być elementem określającym praktykę zarządzania. W kontekście obecnych przemian globalizacyjnych stosowana polityka kierowania definiowana jest przede wszystkim pod względem funkcjonalnym, a nie politycznym.

7. Zarządzanie służy osiągnięciu przez jednostkę zamierzonych wyników w otoczeniu zewnętrznym, w którym ów podmiot działa; stąd skupienie się współczesnych organizacji na zarządzaniu skierowanym na zewnątrz - outward directed management [Drucker 1998, s. 178]. Zarząd istnieje po to, aby określać pożądane rezultaty oraz optymalnie alokować zasoby organizacji w celu osiągnięcia zamierzonych na zewnątrz wyników.

Esencją nauki o zarządzaniu, jak wynika z rozważań P.F. Druckera, powinna stać się dewiza, że ,przedmiotem troski zarządu i jego odpowiedzialnością jest wszystko, co wpływa na sprawność działania instytucji i jej wyniki - zarówno wewnątrz, jak i na zewnątrz, zarówno pod, jak i zupełnie poza kontrolą instytucji” [Drucker 2002, s. 113].

Przesłanki zmiany założeń teorii zarządzania są powiązane bezpośrednio z przemianami zachodzącymi w otoczeniu organizacji i coraz większą złożonością procesów wewnętrznych. Wzrastająca nieprzewidywalność zmian o charakterze gospodarczym zmusza zarządzających do podejmowania decyzji w sytuacji posiadania niekompletnych informacji i braku możliwości wyznaczenia prognoz dotyczących przyszłości. Największy wpływ na ewolucję paradygmatów zarządzania miały procesy globalizacyjne, prowadzące nieustannie do ujednolicania rynków i tworzące globalną konkurencję, oraz konieczność dostosowania się do warunków otoczenia międzynarodowego. Procesy te wpływają nie tylko na otoczenie organizacji, ale również na jej wnętrze. Rozwój przedsiębiorstw, ich łączenie się i zawieranie aliansów spowodowały konieczność wprowadzenia zmian w strukturach organizacyjnych, w kierunku tworzenia interdyscyplinarnych zespołów, których członkowie posiadają różnorodną wiedzę i umiejętności. Zmiany związane z oczekiwaniami wobec pracowników oraz podejściem do ich możliwości i umiejętności stały się częścią rozważań nad teorią zarządzania. Ewolucja tych uwarunkowań ukształtowała treść nowego paradygmatu. M.D. Hansen opisuje stopniową ewolucję tego paradygmatu. Wywodzi się ona od naukowego zarządzania, poprzez paradygmat relacji międzyludzkich i zasobów ludzkich, gdzie pracownik jest w coraz większym stopniu traktowany indywidualnie, przez pryzmat przekazywania swoich umiejętności i wiedzy na korzyść organizacji. Ostatecznym elementem tej ewolucji jest ukazanie pracowników jako 
kapitału ludzkiego, który dzięki wykorzystaniu swoich wewnętrznych zasobów (postać nie tylko fizyczna i psychiczna, ale też duchowa) prowadzi organizację w stronę poprawy jej efektywności [Hansen 2009]. W koncepcji tej wskazuje się na to, że wszystkie paradygmaty znajdują zastosowanie we współczesnych przedsiębiorstwach, lecz z uwagi na różnice w poziomie ich rozwoju nie można jednoznacznie stwierdzić, który z przedstawionych modeli jest najlepszy.

Szybkość procesów globalizacyjnych spowodowała przyspieszenie zmian technologicznych, rozszerzanie się badań nad nowymi technologiami oraz rozprzestrzenianie się wiedzy. Konsekwencjami płynącymi z owych przekształceń są coraz krótsze cykle kreowania produktów i wprowadzania ich na rynek oraz zredukowana długość życia produktów [Mazurkiewicz 2011, s. 408-418]. Zachodzące zmiany dotyczą całościowo funkcjonowania jednostek gospodarczych, a ich tempo i wzrost złożoności turbulentnego otoczenia sprawiają, że nieustannie zmieniają się realia prowadzenia działalności.

W kontekście przedstawionych przemian dochodzi do formułowania się nowych czynników, będących wyznacznikami sukcesu w hiperkonkurencyjnym otoczeniu. Ciągłe zmiany w sposobie prowadzenia biznesu prowadzą do drugiej rewolucji menedżerskiej, w której tworzą się nowe koncepcje zarządzania, a wcześniejsze ulegają weryfikacji. Obecnie nie ma uniwersalnego sposobu prowadzenia działalności gwarantującego sukces. W związku z tym postrzeganie rzeczywistości biznesowej jest w wielu przypadkach niespójne. Determinuje to różnice w koncepcjach dotyczących głównych założeń świata zarządzania.

Koncepcja paradygmatów zarządzania P.F. Druckera stała się punktem wyjścia dla I.K. Hejduk, W.M. Grudzewskiego, A. Sankowskiej oraz M. Wańtuchowicz. Podjęli oni próbę określenia czterech paradygmatów, które wzajemnie na siebie oddziałują, wspólnie tworząc model idealnego przedsiębiorstwa (sustainable enterprise). Stworzony w ten sposób diament składa się z czterech istotnych dla budowania trwałego sukcesu przedsiębiorstwa cech, tj. zaufania, wiedzy, innowacji i przedsiębiorczości [Hejduk i in. 2010].

W.M. Grudzewski [2006] dodatkowo określa teorie, które wpłynęły na współczesne zarządzanie. Wśród nich wymienia: teorie systemów, podejście behawioralne, sytuacyjne, ukierunkowane na kulturę, dążenie do doskonałości i wdrażanie do praktyki gospodarczej organizacji inteligentnej. W tabeli 1 zaprezentowano ewolucję paradygmatów zarządzania, będącą opracowaniem W.M. Grudzewskiego.

Kwintesencją przedstawionej koncepcji jest stwierdzenie, że kadra zarządzająca w organizacjach powinna doskonalić zestaw umiejętności o charakterze technicznym, społeczno-kulturowym oraz funkcjonalnym. Postawa ta ma służyć sprostaniu nowemu paradygmatowi, który zmienia zakres odpowiedzialności menedżerów, ich ryzyko oraz możliwość sprawowania kontroli. W.M. Grudzewski porównuje menedżerów do „filarów i architektów organizacyjnej konkurencyj- 
ności łączących ludzi, możliwości i zasoby, przy jednoczesnym unikaniu zagrożenia" [Grudzewski 2006, s. 11-13].

Tabela 1. Ewolucja paradygmatów zarządzania - koncepcja I

\begin{tabular}{|l|l|}
\hline \multicolumn{1}{|c|}{ Tradycyjny paradygmat } & \multicolumn{1}{c|}{ Nowy paradygmat } \\
\hline $\begin{array}{l}\text { Redukcja bezpośrednich kosztów produkcji } \\
\text { jako pierwszoplanowy przedmiot uwagi zarzą- } \\
\text { dzana }\end{array}$ & $\begin{array}{l}\text { Redukowanie pośrednich kosztów przedsię- } \\
\text { biorstwa przy jednoczesnym osiąganiu wyso- } \\
\text { kiej konkurencyjności }\end{array}$ \\
$\begin{array}{l}\text { Operacje przedsiębiorstwa charakteryzowane } \\
\text { jako stabilne }\end{array}$ & $\begin{array}{l}\text { Operacje elastyczne, zwinne i ciągle doskona- } \\
\text { lone na potrzeby zmian }\end{array}$ \\
\hline $\begin{array}{l}\text { Linie produktów oparte na pojedynczej, szcze- } \\
\text { gólnie ważnej technologii przy zachowaniu } \\
\text { długich okresów życia produktów }\end{array}$ & $\begin{array}{l}\text { Linie produktów i technologii wieloognisko- } \\
\text { wych (multi-core) przy zaistniałych krótkich } \\
\text { okresach życia produktów }\end{array}$ \\
\hline $\begin{array}{l}\text { Kierownicy traktowani jako decydenci, a pra- } \\
\text { cownicy jako bierni wykonawcy poleceń }\end{array}$ & $\begin{array}{l}\text { Kierownicy traktowani jako instruktorzy uła- } \\
\text { twiający pracę (coaches/facilitators), a ludzie } \\
\text { jako pracownicy wiedzy/kapitał intelektualny }\end{array}$ \\
\hline $\begin{array}{l}\text { Rynki światowe podzielone według kryteriów } \\
\text { narodowych; firmy narodowe dominują na } \\
\text { miejscowych rynkach }\end{array}$ & $\begin{array}{l}\text { Globalne rynki światowe, większa uwaga skie- } \\
\text { rowana na rozwój międzynarodowych struktur } \\
\text { gospodarczych i politycznych }\end{array}$ \\
\hline
\end{tabular}

Źródło: [Grudzewski 2006, s. 13].

Nieco późniejsza koncepcja, której twórcą jest D. Jamali, przedstawia zmieniające się założenia nauk o zarządzaniu, wskazując 6 kluczowych elementów kreujących rzeczywistość. Tabela 2 przedstawia te założenia oraz ich opis.

Tabela 2. Kluczowe zasady paradygmatu zarządzania

\begin{tabular}{|l|l|}
\hline Jakość & Jakość jako fundamentalny wymóg decydujący o konkurencyjności \\
\hline Reagowanie & Reagowanie na zmiany otoczenia zewnętrznego i oczekiwania klientów \\
\hline Zwinność & Elastyczność w komunikacji i operacjach \\
\hline Innowacja & Pielęgnowanie nowych idei, spożytkowanie kreatywności i entuzjazmu ludzi \\
\hline Integracja & Integracja portfela technologii dla (uzyskania) wyraźnej przewagi konkurencyjnej \\
\hline $\begin{array}{l}\text { Zespołowość } \\
\text { (teaming) }\end{array}$ & $\begin{array}{l}\text { Kreowanie i rozwijanie zdecentralizowanych, wielofunkcyjnych i wielodyscypli- } \\
\text { narnych zespołów w przedsiębiorstwie }\end{array}$ \\
\hline
\end{tabular}

Źródło: [Jamali 2005], za: [Grudzewski 2006, s. 11].

Kolejna koncepcja, bardziej szczegółowo odnosząca się do praktyki zarządzania, prezentowana jest przez M. Ferguson. Przedstawia ona zbiór zasadniczych różnic pomiędzy nieaktualnymi już uwarunkowaniami prowadzenia organizacji i nowymi, obowiązującymi obecnie paradygmatami zarządzania [Ferguson 1993, s. 49-60]. Autorka odnosi się do kilku grup zagadnień: zasobów ludzkich, orga- 
nizacji procesów i uwarunkowań zewnętrznych jako wyznaczników sprawnego zarządzania.

Tabela 3. Ewolucja paradygmatów zarządzania - koncepcja II

\begin{tabular}{|c|c|}
\hline Tradycyjny paradygmat & Nowy paradygmat \\
\hline Promowanie konsumpcji za wszelką cenę & Odpowiednia, umiarkowana konsumpcja \\
\hline Dopasowanie ludzi do pracy & Dopasowanie pracy do ludzi \\
\hline $\begin{array}{l}\text { Narzucanie celów, podejmowanie decyzji } \\
\text { w kategoriach top-down }\end{array}$ & $\begin{array}{l}\text { Prowadzenie działań w stronę autonomii pra- } \\
\text { cowników, kreowanie postawy uczestniczącej }\end{array}$ \\
\hline Podział pracy i ról w organizacji & $\begin{array}{l}\text { Wymiana doświadczeń specjalistów w kontek- } \\
\text { ście poszerzenia ich kompetencji }\end{array}$ \\
\hline Identyfikowanie się z wykonywaną pracą & $\begin{array}{l}\text { Poczucie tożsamości wykraczające poza samo } \\
\text { stanowisko pracy (aspekt organizacyjny) }\end{array}$ \\
\hline $\begin{array}{l}\text { Stały, uporządkowany model prowadzenia } \\
\text { przedsiębiorstwa }\end{array}$ & $\begin{array}{l}\text { Niepewność jako nieodłączny element prowa- } \\
\text { dzenia działalności }\end{array}$ \\
\hline Agresywne konkurowanie & Kooperacja \\
\hline Oddzielenie pracy od przyjemności & Łączenie pracy i przyjemności \\
\hline Manipulacja i dominacja zarządzających & Łączność z naturą \\
\hline Walka o stabilizację & Identyfikacja nadchodzących, ciągłych zmian \\
\hline Podejście ilościowe & Podejście jakościowe oraz ilościowe \\
\hline $\begin{array}{l}\text { Ściśle ekonomiczne motywy prowadzenia } \\
\text { działalności }\end{array}$ & $\begin{array}{l}\text { Wartości duchowe przekraczające korzyści } \\
\text { materialne }\end{array}$ \\
\hline Zarządzanie spolaryzowane & $\begin{array}{l}\text { Przekraczanie założeń zarządzania spolaryzo- } \\
\text { wanego }\end{array}$ \\
\hline $\begin{array}{l}\text { Krótkowzroczne podejście do realizowanej } \\
\text { działalności }\end{array}$ & Poczucie wrażliwości ekologicznej \\
\hline Racjonalizm podejmowanych działań & Podejście racjonalne i intuicyjne \\
\hline Nacisk na rozwiązania krótkoterminowe & $\begin{array}{l}\text { Efektywność osiągana na szeroką skalę musi } \\
\text { uwzględniać harmonię środowiska pracy }\end{array}$ \\
\hline Scentralizowana działalność operacyjna & $\begin{array}{l}\text { Zdecentralizowana działalność operacyjna, } \\
\text { jeżeli to możliwe }\end{array}$ \\
\hline Niedopasowana, niedostosowana technologia & Odpowiednia, dopasowana technologia \\
\hline Alopatyczne eliminowanie zagrożeń & Zrozumienie przyczyn dysharmonii \\
\hline
\end{tabular}

Źródło: opracowanie własne na podstawie [Ferguson 1993, s. 49-60].

Część opracowań dotyczących paradygmatów zarządzania ogranicza się do opisu i analizy jednego kluczowego elementu. Przykładem jest wspomniane już opracowanie M.D. Hansena [2009] bądź publikacja Doktryna jakości [Blikle 2011], wskazująca uwarunkowania procesu produkcji i kreowania produktów przez pryzmat odpowiednich standardów wykonania. O znaczeniu jakości we 
współczesnym biznesie świadczy liczba i popularność koncepcji zarządzania jakością. W kontekście jakości postrzegana jest również satysfakcja konsumenta, zatem realizowane jest podejście marketingowe firm [Blikle 2011]. Tylko sprostanie wymogom rzeczywistości w postaci odpowiedniego podejścia do ludzi i wytwarzanych produktów gwarantuje firmom sukces rynkowy.

Chcąc przedstawić pełny obraz aktualnych paradygmatów w praktyce zarządzania organizacjami, należy zwrócić również uwagę na podejście przedstawione w publikacji pod redakcją W. Kowalczewskiego [Współczesne paradygmaty... 2008]. Opracowanie to podkreśla rolę uwarunkowań gospodarczych oraz wewnętrznych w organizacjach, wskazując kierunki przekształceń i drogę współczesnych organizacji do tworzenia pozycji rynkowej. Opisywane zmiany podkreślają znaczenie jakości zarządzania w procesie uzyskiwania przewagi konkurencyjnej, a także połączenia marketingu i logistyki jako nadrzędnych elementów procesu zarządzania. Autorzy uwypuklają znaczenie ewolucji paradygmatów zarządzania w stronę optymalnego systemu kierowania ludźmi oraz nauki o zarządzaniu środowiskiem. Wiedza oraz odpowiednie jej wykorzystanie, a także jakość i przenikliwość organizacji będą stanowić podstawę prowadzenia biznesu w XXI w. [Wspótczesne paradygmaty... 2008].

W teorii zarządzania oprócz prób określenia aktualnych nowych paradygmatów podejmowane są również starania, by określić siłę oddziaływania starych paradygmatów we współczesnych realiach. J. Pinto [2012] zwraca uwagę na błędy w zarządzaniu popełniane przez organizacje, które kontynuują przekonanie o poprawności starych paradygmatów. Wymienia też kluczowe błędy związane przede wszystkim z nieelastycznym podejściem, niedostosowaniem do turbulentnego otoczenia oraz sztywnym podejściem do zmian zachodzących wewnątrz organizacji.

\section{Paradygmaty zarządzania - odniesienie do spółek indeksu WIG-Spożywczy}

W celu analizy praktycznej realizacji nowoczesnych paradygmatów zarządzania dokonano analizy holistycznego podejścia menedżerów we wszystkich spółkach badanego indeksu i przedstawiono tabelarycznie ich ujęcie w wybranych, najbardziej zaangażowanych w te działania podmiotach. Kolejno przedstawione i analizowane paradygmaty uwarunkowały aktualne podejście i stan istniejący w zakresie internacjonalizacji działań, sposobu prowadzenia działalności operacyjnej, podejścia do kapitału ludzkiego, zarządzania jakością, ochrony środowiska naturalnego, działań marketingowych i dbałości o rozwój technologiczny. 
Tabela 4. Paradygmat I. Internacjonalizacja - brak terytorialnego ograniczenia prowadzenia działalności

\begin{tabular}{|l|l|l|}
\hline \multicolumn{1}{|c|}{ Spółka } & \multicolumn{1}{|c|}{ Obecne działania } & \multicolumn{1}{|c|}{ Kierunki działań } \\
\hline Astarta Holding NV & Ciągły wzrost eksportu & $\begin{array}{l}\text { Firma planuje rozsze- } \\
\text { rzyć eksport poprzez } \\
\text { wchodzenie na nowe } \\
\text { rynki, np. Rosji i UE, jak } \\
\text { również krajów WNP }\end{array}$ \\
\hline $\begin{array}{l}\text { Polski Koncern } \\
\text { Mięsny Duda SA }\end{array}$ & $\begin{array}{l}\text { Uprawnienia umożliwiające eksport do krajów } \\
\text { Unii Europejskiej, a także na bardzo wyma- } \\
\text { gające rynki azjatyckie - Korei Południowej } \\
\text { i Japonii. Eksport do takich krajów, jak Litwa, } \\
\text { Łotwa, Niemcy, Holandia, Irlandia, Francja, } \\
\text { Mołdawia, Macedonia, Rumunia, Serbia, Gre- } \\
\text { cja, Hiszpania i Portugalia. Sprzedaż na rynki } \\
\text { Białorusi i Kazachstanu, Ghany, Gwinei i Antyli } \\
\text { Holenderskich. Firma jest obecna na rynkach } \\
\text { azjatyckich: w Korei, Hongkongu i Japonii }\end{array}$ & \\
\hline Indykpol SA & $\begin{array}{l}\text { Firma na rynkach zagranicznych lokuje około } \\
\text { 30\% produkcji. Eksportuje do Rosji, Niemiec } \\
\text { i na Ukrainę }\end{array}$ & $\begin{array}{l}\text { Kraje azjatyckie - ze } \\
\text { szczególnym z nasta- } \\
\text { wieniem na Chiny }\end{array}$ \\
\hline
\end{tabular}

Źródło: opracowanie własne na podstawie informacji zawartych na stronach internetowych badanych firm oraz ich sprawozdań finansowych, http://www.astartakiev.com/; http://www.pkmduda. pl/; http://www.indykpol.pl/ (dostęp: 25.06.2013).

Przeprowadzona analiza działań związanych z pierwszym paradygmatem dotyczącym internacjonalizacji potwierdza, że badane firmy są zainteresowane lokowaniem swoich zakładów i produktów na rynkach międzynarodowych, które nie ograniczają się do krajów sąsiednich. Coraz powszechniejszymi kierunkami stają się rynki Dalekiego Wschodu, których potencjał i możliwości rozwojowe doceniają menedżerowie. Za najbardziej spektakularne działania badanych firm w tym obszarze należy uznać poszerzanie rynków zbytu przez Astartę Holding NV z siedzibą w Amsterdamie, Polski Koncern Mięsny Duda SA w Warszawie oraz Indykpol SA w Olsztynie (tabela 4).

W badanym okresie zauważalne są starania firm zmierzające do unowocześniania działalności operacyjnej przez modernizację procesów wewnętrznych, jak również wprowadzanie nowoczesnych metod zarządzania. Firmy dbają o unowocześnianie parków maszynowych, wdrażanie programów restrukturyzacji, poprawianie organizacji i wydajności pracy, specjalizacje produktowe, poszukiwanie alternatywnych dostawców i wykorzystanie efektu skali. Menedżerowie firm biorą pod uwagę konieczność adaptacji do warunków rynkowych z jednoczesną orientacją na klienta, zarówno w kraju, jak i za granicą. Wyraźnym tego przykładem w spółkach przemysłu spożywczego są działania firmy: Kofola SA w Kutnie, 


\section{Polskiego Koncernu Mięsnego Duda SA w Warszawie oraz Indykpolu SA w Olsz- tynie (tabela 5).}

Tabela 5. Paradygmat II. Sposób prowadzenia działalności operacyjnej - procesy wewnętrzne, ich złożoność i zarządzanie nimi

\begin{tabular}{|c|c|c|}
\hline Spółka & Obecne działania & Kierunki działań \\
\hline $\begin{array}{l}\text { Kofola SA } \\
\text { w Kutnie }\end{array}$ & $\begin{array}{l}\text { Produkcja zdrowych napojów o niższej niż } \\
\text { w konkurencyjnych zawartości cukru, napoje } \\
\text { z wyciągami z ziół i drzew, wprowadzenie napojów } \\
\text { na bazie stewii, uruchomienie w } 2011 \text { r. linii do } \\
\text { gorącego rozlewu, wchodzenie w rynek on-the-go, } \\
\text { zwiększenie udziału małych formatów w ofercie, } \\
\text { zwiększenie liczby obsługiwanych restauracji } \\
\text { (uruchomienie bezpośredniej dystrybucji na } \\
\text { Słowacji pod koniec } 2009 \text { r.), utworzenie zespołu } \\
\text { handlowców pozyskujących lokale gastronomiczne } \\
\text { w Czechach, systematyczna praca nad obniżeniem } \\
\text { kosztów produkcji i logistyki, zespół do obsługi } \\
\text { dyskontów spożywczych i produktów private label, } \\
\text { obsługa segmentu marek dedykowanych w Polsce } \\
\text { i Czechach, tworzenie wartości dodanej dla } \\
\text { klienta, wprowadzanie światowych marek na bazie } \\
\text { posiadanej platformy produkcyjno-dystrybucyjnej, } \\
\text { wprowadzanie innowacji trafiających w gusta sze- } \\
\text { rokiego grona klientów, tzw. mainstream, zaanga- } \\
\text { żowanie użytkowników w tworzenie pozytywnych } \\
\text { emocji związanych z markami }\end{array}$ & $\begin{array}{l}\text { Do } 2017 \text { r. spółka chce } \\
\text { stać się dominującą } \\
\text { firmą w segmencie } \\
\text { HoReCa i produktów } \\
\text { impulsowych, wpły- } \\
\text { wając na cały rynek } \\
\text { w Czechach i na Sło- } \\
\text { wacji. Ma zamiar sta- } \\
\text { bilizować zyskowność } \\
\text { kanału detalicznego } \\
\text { i oferować coraz zdrow- } \\
\text { sze wersje produktów } \\
\text { o najwyższej jakości }\end{array}$ \\
\hline $\begin{array}{l}\text { Polski Koncern } \\
\text { Mięsny Duda SA }\end{array}$ & $\begin{array}{l}\text { Budowa w grupie wzajemnie uzupełniających } \\
\text { się firm oraz rozsądna dywersyfikacja inwesty- } \\
\text { cji w ramach branży. Grupa realizuje strategię } \\
\text { konsolidacji branży, analizując możliwości przejęć } \\
\text { kolejnych podmiotów działających w różnych seg- } \\
\text { mentach rynku mięsnego, zwłaszcza w dystrybucji } \\
\text { oraz przetwórstwie }\end{array}$ & $\begin{array}{l}\text { Intensywny rozwój } \\
\text { sieci dystrybucji mięs } \\
\text { i wędlin w kraju, } \\
\text { ekspansja w sektorze } \\
\text { przetwórczym i rozwój } \\
\text { własnych marek }\end{array}$ \\
\hline Indykpol SA & $\begin{array}{l}\text { Controlling kosztów na wszystkich szczeblach } \\
\text { organizacji, wdrożenie programu restrukturyzacji } \\
\text { kosztów pracy Impac, wdrożenie nowoczesnych } \\
\text { technologii, wdrożenie zintegrowanego systemu } \\
\text { komputerowego, który gwarantuje najlepszą wiedzę } \\
\text { o procesach i efektach ekonomicznych działalności } \\
\text { oraz stanowi podstawę do redukcji kosztów zarzą- } \\
\text { dzania, wdrożenie programu integracji produkcji } \\
\text { żywca drobiowego, który zapewnia najniższe } \\
\text { koszty w sferze surowcowej }\end{array}$ & $\begin{array}{l}\text { Stałe poprawianie } \\
\text { organizacji i wydajno- } \\
\text { ści pracy, konsolidacja } \\
\text { spółek w ramach grupy } \\
\text { kapitałowej i specja- } \\
\text { lizacja produktowa } \\
\text { umożliwiająca wyko- } \\
\text { rzystanie efektu skali } \\
\text { we wszystkich sferach } \\
\text { działalności firmy }\end{array}$ \\
\hline
\end{tabular}

Źródło: opracowanie własne na podstawie informacji zawartych na stronach internetowych badanych firm oraz ich sprawozdań finansowych, http://www.kofola.pl/; http://www.pkmduda.pl/; http:// www.indykpol.pl/ (dostęp: 26.06.2013). 
Tabela 6. Paradygmat III. Podejście do kapitału ludzkiego - pracownicy jako zasób organizacji i jednostki

\begin{tabular}{|l|l|l|}
\hline \multicolumn{1}{|c|}{ Spółka } & \multicolumn{1}{|c|}{ Obecne działania } & \multicolumn{1}{|c|}{ Kierunki działań } \\
\hline $\begin{array}{l}\text { AB Agrowill } \\
\text { Group }\end{array}$ & $\begin{array}{l}\text { Przedsiębiorstwo jest zobowiązane dbać o lojal- } \\
\text { nych wobec niego pracowników - dobrzy i nie- } \\
\text { zawodni pracownicy powinni być motywowani } \\
\text { wynagrodzeniem proporcjonalnym do osiągnię- } \\
\text { tych rezultatów. Każdy pracownik powinien } \\
\text { dbać o środki pracy i nie tylko chronić, lecz } \\
\text { również podnosić wartość majątku }\end{array}$ & $\begin{array}{l}\text { Wzmacnianie kapitału } \\
\text { ludzkiego przez system } \\
\text { szkolen i podnoszenie } \\
\text { umiejętności i kompeten- } \\
\text { cji pracowniczych }\end{array}$ \\
\hline $\begin{array}{l}\text { Astarta Holding } \\
\text { NV }\end{array}$ & $\begin{array}{l}\text { Jedną z wartości jest praca w zespole, w którym } \\
\text { każdy pracownik jest profesjonalistą. Spółka } \\
\text { zwraca uwagę na osobisty i zawodowy rozwój } \\
\text { pracowników firmy, zapewniając korzystne } \\
\text { warunki środowiska pracy; to wszystko wpływa } \\
\text { na postawy twórcze specjalistów, wysoką wydaj- } \\
\text { ność pracy i niską rotację personelu. Specjaliści } \\
\text { spółki biorą udział w szkoleniach, konferen- } \\
\text { cjach, seminariach zarówno na Ukrainie, jak i za } \\
\text { granicą, np. specjaliści z branży rolnej uczest- } \\
\text { niczyli w międzynarodowych konferencjach na } \\
\text { Białorusi, w krajach bałkańskich i w Egipcie }\end{array}$ & $\begin{array}{l}\text { Planowane jest dalsze } \\
\text { uczestnictwo specjalistów } \\
\text { w europejskich szkole- } \\
\text { niach i konferencjach } \\
\text { międzynarodowych }\end{array}$ \\
\hline $\begin{array}{l}\text { Zakłady Przemy- } \\
\text { słu Cukierniczego } \\
\text { Mieszko SA }\end{array}$ & $\begin{array}{l}\text { Zarządzanie zasobami ludzkimi to jedna } \\
\text { z głównych zasad polityki personalnej firmy. } \\
\text { Firma dąży do współpracy z ambitnymi, kompe- } \\
\text { tentnymi osobami, które pragną rozwijać swoje } \\
\text { umiejętności oraz poszerzać zakres wiedzy. Dla } \\
\text { firmy ważne jest pozyskiwanie zaangażowanych } \\
\text { i otwartych pracowników. Dla osiągnięcia tych } \\
\text { celów stosuje profesjonalne zasady rekrutacji. } \\
\text { Pracownicy jako praktycy znający realia firmy } \\
\text { posiadają ogromną wiedzę i umiejętności prak- } \\
\text { tyczne }\end{array}$ & $\begin{array}{l}\text { Firma ma zamiar nadal } \\
\text { inwestować w rozwój } \\
\text { pracowników, prowadząc } \\
\text { intensywny program } \\
\text { szkoleń. Stawia na } \\
\text { szkolenia wewnętrzne } \\
\text { i oferuje bogaty pakiet } \\
\text { szkoleń zewnętrznych }\end{array}$ \\
\hline
\end{tabular}

Źródło: opracowanie własne na podstawie informacji zawartych na stronach internetowych badanych firm oraz ich sprawozdań finansowych, http://www.agrowill.lt/pl; http://www.astartakiev. com/; http://www.mieszko.pl/pl (dostęp: 28.06.2013).

Spółki spożywcze coraz częściej zaczynają doceniać rolę kapitału ludzkiego jako znaczącego zasobu w generowaniu zysków firmy (tabela 6). Menedżerowie firm przeznaczają część dochodów na szkolenia i podnoszenie umiejętności pracowników. Kompetencje pracowników zaczynają stanowić o pozycji firmy, osiąganych przez nią dochodach oraz postrzeganiu przez konkurencję. Wiele firm zaczyna inwestować w praktyki studenckie, które w późniejszym okresie zaowocują pozyskaniem wysoko wykwalifikowanych pracowników. Nie zapomina się także o umożliwianiu rozwoju zawodowego osobom niepełnosprawnym. 
Tabela 7. Paradygmat IV. Jakość procesów, wyrobów i zarządzanie jakością

\begin{tabular}{|c|c|c|}
\hline Spółka & Obecnie działania & Kierunki działań \\
\hline Colian SA & $\begin{array}{l}\text { Firma stawia na jakość, co jest jej priorytetem; } \\
\text { uważa, że jakość produktów spożywczych jest dla } \\
\text { konsumentów sprawą kluczową. Monitorowanie } \\
\text { i poprawa jakości w spółce Jutrzenka Colian } \\
\text { odbywa się na każdym etapie produkcji oraz dys- } \\
\text { trybucji. Audyty i kontrole wewnętrzne obejmują: } \\
\text { dostawców surowców oraz opakowań produktów, } \\
\text { procesy technologiczne i linie produkcyjne oraz } \\
\text { gotowe produkty. W celu sprostania wymaganiom } \\
\text { klientów i ciągłego doskonalenia wprowadzono } \\
\text { w zakładach spółki systemy jakości; standardy } \\
\text { jakości opracowane są przez dominujące na rynku } \\
\text { niemieckie, brytyjskie i francuskie sieci han- } \\
\text { dlowe, które wymagają ich przestrzegania }\end{array}$ & $\begin{array}{l}\text { Firma stawia na rozwój } \\
\text { rynku spożywczego } \\
\text { w Polsce, poprawę jego } \\
\text { kondycji i wizerunku } \\
\text { polskiej żywności } \\
\text { w kraju i na świecie. } \\
\text { Widzi perspektywy } \\
\text { w zakresie podnosze- } \\
\text { nia jakości produktów } \\
\text { z wykorzystaniem } \\
\text { inwestycji zagranicz- } \\
\text { nych i szeroko współ- } \\
\text { pracujących ze sobą } \\
\text { firm spożywczych }\end{array}$ \\
\hline $\begin{array}{l}\text { Zakłady Przemysłu } \\
\text { Cukierniczego } \\
\text { Mieszko SA }\end{array}$ & $\begin{array}{l}\text { Produkty firmy spełniają normy wymagane prze- } \\
\text { pisami prawa żywnościowego oraz specyficzne } \\
\text { oczekiwania klientów; spełniane są wymagania } \\
\text { dotyczące jakości surowców i opakowań stoso- } \\
\text { wanych do produkcji, które dostarczane są przez } \\
\text { renomowanych dostawców. Nie stosuje się surow- } \\
\text { ców modyfikowanych genetycznie. Pracownicy } \\
\text { firmy dbają o bezpieczeństwo zdrowotne produk- } \\
\text { tów w ramach wdrożonych systemów zarządzania } \\
\text { jakością i bezpieczeństwa żywności }\end{array}$ & $\begin{array}{l}\text { Dalsze kształtowanie } \\
\text { świadomości jakościo- } \\
\text { wej poprzez szeroki } \\
\text { zakres realizowanych } \\
\text { szkoleń i efek- } \\
\text { tywną komunikację } \\
\text { wewnętrzną }\end{array}$ \\
\hline Pamapol SA & $\begin{array}{l}\text { Doskonalenie zintegrowanego systemu zarządza- } \\
\text { nia jakością, zgodnego z wymaganiami normy } \\
\text { PN-EN ISO 9001:2001 i systemu zarządzania } \\
\text { bezpieczeństwem żywności zgodnego z wymaga- } \\
\text { niami normy PN-EN ISO 22000:2006 ma na celu } \\
\text { produkcję bezpiecznej żywności, wzrost zaufania } \\
\text { klientów oraz poprawę organizacji pracy i komu- } \\
\text { nikacji wewnętrznej. W roku } 2007 \text { w zakładzie } \\
\text { Pamapol SA w Ruścu zostały wdrożone między- } \\
\text { narodowe systemy jakości - IFS/BRC, dzięki } \\
\text { czemu spełnione są szczegółowe wymagania } \\
\text { dotyczące bezpieczeństwa produktów }\end{array}$ & $\begin{array}{l}\text { Dalsze unowocześnia- } \\
\text { nie hal produkcyjnych } \\
\text { i utrzymywanie wydaj- } \\
\text { nych linii technolo- } \\
\text { gicznych; dbałość } \\
\text { o realizację i spełnianie } \\
\text { norm ISO i wytycznych } \\
\text { międzynarodowych } \\
\text { systemów jakości }\end{array}$ \\
\hline
\end{tabular}

Źródło: opracowanie własne na podstawie informacji zawartych na stronach internetowych badanych firm oraz ich sprawozdań finansowych, http://www.jutrzenka.com.pl/; http://www.mieszko.pl/ pl; http://pamapol.com.pl/pl (dostęp: 27.06.2013).

Po prawie dekadzie uczestnictwa w unijnych strukturach gospodarczych przyszedł czas na zmianę podejścia polskich producentów żywności, którzy zaczynają zauważać, że na rynku nie wystarczy już konkurować ceną. Aby stworzyć produkt najwyższej jakości, należy zadbać o wysokie standardy produkcyjne i użycie właści- 
wych surowców. W spełnianiu tych celów pomocne są uzyskiwane certyfikaty jakości systemu zarządzania jakością i środowiskiem. Standardem stało się stosowanie przez firmy systemu analizy zagrożeń i krytycznych punktów kontroli HACCP (tabela 7).

Tabela 8. Paradygmat V. Środowisko naturalne, ochrona, zapewnienie minimalnego stopnia zanieczyszczenia

\begin{tabular}{|c|c|c|}
\hline Spółka & Obecne działania & Kierunki działań \\
\hline $\begin{array}{l}\text { Astarta Hol- } \\
\text { ding NV }\end{array}$ & $\begin{array}{l}\text { Firma ma określoną politykę ochrony środowi- } \\
\text { ska, wymienia ochronę jako wartość, zgodnie } \\
\text { z którą realizuje swoje funkcje }\end{array}$ & \begin{tabular}{|l} 
Firma planuje znacząco \\
zmniejszyć zużycie gazu \\
ziemnego w swoich cukrow- \\
niach, co z kolei prowadzi do \\
mniejszej emisji dwutlenku \\
węgla odpowiedzialnego za \\
efekt cieplarniany
\end{tabular} \\
\hline $\begin{array}{l}\text { Zakłady } \\
\text { Tłuszczowe } \\
\text { Kruszwica SA }\end{array}$ & $\begin{array}{l}\text { W trosce o ochronę środowiska naturalnego } \\
\text { kierownictwo ZT Kruszwica SA zobowiązuje } \\
\text { się do prowadzenia swojej działalności według } \\
\text { następujących zasad: } \\
\text { - przestrzeganie wszelkich regulacji prawnych } \\
\text { dotyczących środowiska, } \\
\text { - rozwijanie i stosowanie zasad zarządzania } \\
\text { środowiskowego jako powszechnej praktyki, } \\
\text { - zmniejszanie wpływu na środowisko poprzez } \\
\text { ciągłe wprowadzanie udoskonaleń w wypo- } \\
\text { sażeniu i technologii oraz zastosowanie naj- } \\
\text { nowszych technologii w programach poprawy, } \\
\text { w szczególności w zakresie poprawy jakości } \\
\text { ścieków oraz redukcji emisji hałasu, } \\
\text { - wspieranie szkoleń i działań promocyjnych } \\
\text { w zakresie ochrony środowiska oraz podno- } \\
\text { szenia świadomości ekologicznej wszystkich } \\
\text { pracowników, } \\
\text { - poprawianie wydajności we wszystkich dzie- } \\
\text { dzinach produkcyjnych w celu zabezpieczenia } \\
\text { przed zanieczyszczeniami środowiska oraz } \\
\text { zmniejszania zużycia surowców i energii }\end{array}$ & $\begin{array}{l}\text { Firma będzie konsekwentnie } \\
\text { dążyć do osiągnięcia następu- } \\
\text { jących celów: } \\
\text { - zmniejszanie negatyw- } \\
\text { nego wpływu na środowisko } \\
\text { spowodowanego działalnością } \\
\text { zakładu, } \\
\text { - poszukiwanie sposobów na } \\
\text { to, by zapobiegać zanieczysz- } \\
\text { czaniu środowiska } \\
\text { Ustanowienie systemu zarzą- } \\
\text { dzania w celu zagwarantowa- } \\
\text { nia ciągłej poprawy sytuacji } \\
\text { w środowisku, w działaniach } \\
\text { produkcyjnych, wyposażeniu } \\
\text { zakładu, stosowanych mate- } \\
\text { riałach, w produktach oraz } \\
\text { świadomości ekologicznej } \\
\text { pracowników }\end{array}$ \\
\hline $\begin{array}{l}\text { Zakłady } \\
\text { Przemysłu } \\
\text { Cukierniczego } \\
\text { Mieszko SA }\end{array}$ & $\begin{array}{l}\text { Działalność gospodarcza firmy oparta jest na } \\
\text { dbałości o otaczające ją środowisko naturalne }\end{array}$ & $\begin{array}{l}\text { Firma zakłada ciągłe dosko- } \\
\text { nalenie stosowanego systemu } \\
\text { zarządzania jakością zgodnego } \\
\text { z międzynarodowymi stan- } \\
\text { dardami dotyczącymi ochrony } \\
\text { środowiska }\end{array}$ \\
\hline
\end{tabular}

Źródło: opracowanie własne na podstawie informacji zawartych na stronach internetowych badanych firm oraz ich sprawozdań finansowych, http://www.ztkruszwica.pl/; http://www.indykpol.pl/; http://www.mieszko.pl/pl (dostęp: 27.06.2013). 
Ogólna presja Unii Europejskiej związana z ochroną środowiska znalazła odzwierciedlenie w funkcjonowaniu spółek spożywczych w Polsce, przejawiając się w konkretnych działaniach firm zmieniających swoje dotychczasowe niejednokrotnie negatywne podejście do tego zagadnienia. Coraz częściej spotykane są zachowania dające gwarancję ciągłej poprawy stanu środowiska naturalnego, jak również podnoszenie świadomości ekologicznej pracowników i konsumentów. Firmy do swych osiągnięć zaczynają zaliczać dbałość o otaczające je środowisko naturalne, co zaczyna być postrzegane jako element wzmacniający wartość rynkową firmy (tabela 8).

Tabela 9. Paradygmat VI. Podejście marketingowe przedsiębiorstwa, dbanie o pozycję konkurencyjną, zdobywanie przewag

\begin{tabular}{|l|l|l|}
\hline \multicolumn{1}{|c|}{ Spółka } & \multicolumn{1}{|c|}{ Obecnie działania } & \multicolumn{1}{c|}{ Kierunki działań } \\
\hline Colian SA & $\begin{array}{l}\text { Menedżerowie firmy przyjęli dewizę: } \\
\text {,Wiemy, nie będziemy już ani więksi, ani } \\
\text { starsi od naszych najgroźniejszych konkuren- } \\
\text { tów. Z całą pewnością możemy być od nich } \\
\text { lepsi”; służy temu pełne zorientowanie na } \\
\text { potrzeby klientów }\end{array}$ & $\begin{array}{l}\text { Firma zakłada dalsze } \\
\text { spełnianie oczekiwań } \\
\text { konsumentów poprzez } \\
\text { wytwarzanie i dystrybucję } \\
\text { produktów żywnościowych } \\
\text { o znakomitej jakości oraz } \\
\text { wyjątkowych walorach } \\
\text { smakowych i odżywczych }\end{array}$ \\
\hline Indykpol SA & $\begin{array}{l}\text { Orientacja na klienta, otwartość i wiarygod- } \\
\text { ność to podstawy ekspansji handlowej firmy; } \\
\text { według tych wartości spółka doskonali } \\
\text { siebie, stosowane narzędzia i organizację }\end{array}$ & $\begin{array}{l}\text { Firma deklaruje ciągłe } \\
\text { doskonalenie, które zapew- } \\
\text { nia jej przewagę techno- } \\
\text { logiczną i jakościową, co } \\
\text { pośrednio prowadzi do } \\
\text { wzrostu produktywności } \\
\text { i efektywności }\end{array}$ \\
\hline $\begin{array}{l}\text { Zakłady Przemysłu } \\
\text { Cukierniczego } \\
\text { Mieszko SA }\end{array}$ & $\begin{array}{l}\text { Głównym celem ZPC Mieszko SA jest } \\
\text { osiągnięcie wysokiej pozycji rynkowej } \\
\text { wśród renomowanych producentów wyrobów } \\
\text { cukierniczych w Polsce oraz zwiększenie } \\
\text { udziału firmy w rynkach zagranicznych }\end{array}$ & $\begin{array}{l}\text { Firma planuje osiągać } \\
\text { wskazane cele poprzez } \\
\text { stosowanie nowoczesnych } \\
\text { metod zarządzania, ciągły } \\
\text { rozwój i doskonalenie we } \\
\text { wszystkich obszarach dzia- } \\
\text { łania spółki }\end{array}$ \\
\hline
\end{tabular}

Źródło: opracowanie własne na podstawie informacji zawartych na stronach internetowych badanych firm oraz ich sprawozdań finansowych, http://www.jutrzenka.com.pl/; http://www.indykpol.pl/; http://www.mieszko.pl/ (dostęp: 29.06.2013).

W badanych firmach stwierdzono, że pracownicy zainteresowani są ciągłym wprowadzaniem działań marketingowych w przedsiębiorstwie, ich udoskonalaniem i orientowaniem tych działań na klienta, co niewątpliwie wymaga podejmowania decyzji opartych na badaniach marketingowych i zintegrowanym wyko- 
rzystaniu instrumentów marketingowych. Często spotykane działania zmierzające do poprawy konkurencyjności to: zagospodarowanie zbędnych zasobów, pozyskiwanie nowych partnerów biznesowych oraz całościowe postrzeganie pojawiających się problemów (tabela 9).

Tabela 10. Paradygmat VII. Technologia dopasowana do działalności spółki, prowadzenie badań, udoskonalanie produktów, wdrażanie nowych technik

\begin{tabular}{|l|l|l|}
\hline \multicolumn{1}{|c|}{ Spółka } & \multicolumn{1}{|c|}{ Obecne działania } & \multicolumn{1}{|c|}{ Kierunki działań } \\
\hline $\begin{array}{l}\text { Polski Koncern } \\
\text { Mięsny Duda SA }\end{array}$ & $\begin{array}{l}\text { Zakład PKM Duda w Grąbkowie jest jednym } \\
\text { z najnowocześniejszych zakładów mięsnych } \\
\text { w Europie. Korzysta on z zaawansowanych } \\
\text { rozwiązań technologicznych - przemysłowych } \\
\text { i informatycznych - zapewniających wydajnośćć } \\
\text { i sprawność organizacyjną fabryki, opracowa- } \\
\text { nych i wdrożonych przez firmy Banss, Butina, } \\
\text { Taifun i Viessman }\end{array}$ & $\begin{array}{l}\text { Firma prowadzi bieżącą } \\
\text { obserwację postępu tech- } \\
\text { nicznego i planuje dalej } \\
\text { inwestować w zapewnie- } \\
\text { nie sobie miejsca pośród } \\
\text { liderów technologicznych } \\
\text { w swojej branży }\end{array}$ \\
\hline $\begin{array}{l}\text { Makarony } \\
\text { Polskie SA }\end{array}$ & $\begin{array}{l}\text { Proces wytwarzania prowadzony jest na czterech } \\
\text { nowoczesnych liniach produkcyjnych włoskich } \\
\text { firm Pavan i Anselmo. Nowoczesna technologia } \\
\text { THT pozwala uzyskać wysokie temperatury } \\
\text { suszenia, co daje gwarancję bardzo dobrej jako- } \\
\text { ści i czystości mikrobiologicznej makaronu oraz } \\
\text { umożliwia wydłużenie terminów przydatności } \\
\text { do spożycia }\end{array}$ & $\begin{array}{l}\text { Firma prowadzi dalsze } \\
\text { działania mające na celu } \\
\text { poprawę jakości i bezpie- } \\
\text { czeństwa produktów, co } \\
\text { przy w pełni zautomatyzo- } \\
\text { wanej produkcji determi- } \\
\text { nuje inwestycje w nowo- } \\
\text { czesne technologie }\end{array}$ \\
\hline $\begin{array}{l}\text { Zakład posiada nowoczesne hale produkcyjne } \\
\text { wyposażone w 6 wydajnych linii technologicz- } \\
\text { nych, co czyni go jednym z najnowocześniej- } \\
\text { szych tego typu zakładów w Polsce }\end{array}$ & $\begin{array}{l}\text { Firma planuje kolejne } \\
\text { inwestycje (w tym techno- } \\
\text { logiczne), które umożliwią } \\
\text { dalsze dynamiczne zwięk- } \\
\text { szanie skali działania oraz } \\
\text { poprawia efektywność }\end{array}$ \\
\hline
\end{tabular}

Źródło: opracowanie własne na podstawie informacji zawartych na stronach internetowych badanych firm oraz ich sprawozdań finansowych, http://www.makarony.pl/; http://www.pkmduda.pl/; http://pamapol.com.pl/pl (dostęp: 29.06.2013).

Badane firmy jednoznacznie pozytywnie odnoszą się także do potrzeby dopasowania technologii do działalności spółki, konieczności prowadzenia badań naukowych, udoskonalania produktów i wdrażania nowych technik. W większości polskich spółek spożywczych stosowane są najnowocześniejsze parki maszynowe światowej klasy, które są pomocne w wytwarzaniu produktów o najwyższym standardzie. Dzięki badaniom naukowym z kolei producenci zapoznają się z ogólnoświatowymi trendami i technologiami obowiązującymi na rynkach. Tego rodzaju działania są z pewnością korzystne w pozycjonowaniu przedsiębiorstwa przemysłu spożywczego na rynku i przyczyniają się do wzrostu jego wartości (tabela 10). 


\section{Podsumowanie}

Przeprowadzona kwerenda źródłowa dostępnej literatury na temat paradygmatów zarządzania umożliwiła wskazanie tych najbardziej istotnych dla spółek przemysłu spożywczego. Praktyczne zbadanie tych paradygmatów dowiodło, że stanowią one istotny element wspierający bieżącą działalność firm oraz wpływają na podnoszenie ich wartości rynkowej, przez co pozytywnie została zweryfikowana postawiona na wstępie hipoteza badawcza. Reasumując badania zarówno teoretyczne, jak i analityczne dotyczące wpływu nowoczesnych paradygmatów zarządzania na działalność spółek przemysłu spożywczego, można wysunąć następujące wnioski:

1. Spółki spożywcze szczególną uwagę zwracają na jakość wytwarzanych produktów, która według nich determinuje pozycję konkurencyjną przedsiębiorstwa i w niedługim okresie będzie stanowić jedną z najważniejszych przewag rynkowych.

2. Prowadzenie międzynarodowej działalności przestało stanowić barierę w funkcjonowaniu spółek, które uważają ją za wyjście naprzeciw wymogom odbiorców z innych krajów i doskonałą formę promocji wytwarzanego produktu na rynkach międzynarodowych.

3. Menedżerowie badanych spółek dostrzegają potrzebę optymalizacji działalności operacyjnej i stylu zarządzania oraz dostosowania ich do uwarunkowań wewnętrznych organizacji, jak również dopasowania ich do bieżącej sytuacji na rynkach międzynarodowych.

4. Spółki spożywcze ciągle zainteresowane są prowadzeniem badań nad nowymi technologiami, wdrażaniem najnowocześniejszych technologii odpowiednich do prowadzonej działalności.

5. Rozwój kadry kierowniczej oraz pracowników i indywidualne podejście z nastawieniem na rozwój wewnętrzny pracowników stanowią jeden z priorytetowych celów i kierunków działania spółek w przyszłości.

6. Podejście marketingowe w zarządzaniu spółkami przejawia się coraz bardziej w orientacji działań na klienta i nastawieniu na kreowanie dla niego wartości.

\section{Literatura}

Blikle A. [2011], Doktryna jakości, Warszawa, http://firmyrodzinne.pl/download/tqm/ Doktryna-jakosci.pdf.

Drucker P.F. [1998], Management's New Paradigms, „Forbes”, nr 5.

Drucker P.F. [2000], Zarzqdzanie w XXI wieku, Muza, Warszawa.

Drucker P.F. [2002], Myśli przewodnie Druckera, MT Biznes, Warszawa. 
Ferguson M. [1993], A New Consciousness Reader [w:] New Paradigm: Emerging Strategic for Leadership and Organizational Change, eds M. Ray, A. Rinzler, J.P. Tarcher/ Perigee, New York.

Firlej K. [2008a], Stymulanty konkurencyjności w zarzq̨dzaniu spółkami z indeksu WIG-Spożywczy [w:] Zarzqdzanie przedsiębiorstwem w warunkach konkurencji, Uniwersytet Warmińsko-Mazurski, Olsztyn 2008.

Firlej K. [2008b], Zarzqdzanie wiedzq warunkiem rozwoju przedsiębiorstw przemysłu spożywczego [w:] Zarzqdzanie organizacjami w gospodarce opartej na wiedzy. Zasobowe podstawy funkcjonowania i rozwoju organizacji, red. A. Glińska-Neweś, Uniwersytet Mikołaja Kopernika w Toruniu i Towarzystwo Naukowe Organizacji i Kierownictwa Oddział Toruń, Torun 2008.

Grudzewski W.M. [2006], Współczesne kierunki rozwoju nauk o zarzqdzaniu, „Ekonomika i Organizacja Przedsiębiorstwa", nr 3.

Hansen M.D. [2009], The 4 Management Paradigms and the Quantum Leap. Improving Performance, ,Safety XChange”, nr 4, http://www.safetyxchange.org/financing-safety/4-paradigms-quantum-leap.

Hejduk I.K., Grudzewski W.M., Sankowska A., Wańtuchowicz M. [2010], W kierunku zarzqdzania drugiej generacji - model diamentu czterech paradygmatów współczesnego przedsiębiorstwa, „E-mentor”, nr 1(33).

Jamali D. [2005], Changing Management Paradigms: Implications for Educational Institutions, ,Journal of Management Development”, vol. 24, nr 2, http://dx.doi.org/ 10.1108/02621710510579473.

Mazurkiewicz A. [2011], Paradygmaty zarzqdzania we współczesnym przedsiębiorstwie (wybrane aspekty), Zeszyty Naukowe Uniwersytetu Rzeszowskiego, nr 19, Modernizacja dla spójności społeczno-ekonomicznej, Rzeszów.

Pinto J. [2012], New Management Paradigms, „Automation World”, nr 3, www.jimpinto.com. Współczesne paradygmaty nauk o zarzqdzaniu [2008], red. W. Kowalczewski, Difin, Warszawa.

\section{Modern Management Paradigms as an Element of the Value Enhancement of Companies in the Food Industry}

The article looks at modern paradigms of management from a theoretical and analytical point of view. It is assumed that these paradigms play a part in improving how companies in the food industry function. The theoretical part presents an evaluation and the current state of management paradigms. These paradigms are than collated in the aspect of their use in the process of managing food industry companies. Individual management paradigms are then tested for how they work in company operations, noting that their correct use has a significant influence on increasing the company's value and market position. The analysis of operations in this area confirmed that the companies considered here are highly interested in doing what they can to effectively improve their market value, and that they also keep abreast of scientific research as well as their rivals' behaviour. Employing all of these means, they try to accomplish their goals.

Keywords: business management, contemporary paradigms of management, company of the food industry, value and market position of a company. 